\title{
PENGARUH PEMBERIAN TEH HIJAU (Camellia sinensis) TERHADAP TEKANAN DARAH PADA PENDERITA HIPERTENSI
}

\author{
Nunung Sri Mulyani $\mathrm{K}^{1}$ Wiqayatun Arnisam ${ }^{1}$ Putri Ermi ${ }^{1}$ \\ ${ }^{1}$ Jurusan Gizi Politeknik Kesehatan Kemenkes Aceh Jln. Soekarno-Hatta, Lampeunerut, Aceh Besar \\ Corresponding Author: nunungmulyani76@gmail.com
}

\begin{abstract}
Abstrak
Prevalensi hipertensi pada orang dewasa diseluruh dunia sebesar 26,4\% dan di Indonesia sebesar 9,5\%. Di Provinsi Aceh sebesar 30,1\% dan di Aceh Selatan sendiri sebanyak 3255 orang menderita hipertensi. Teh hijau mengandung kombinasi zat yang tidak dimiliki minuman lain diantaranya kafein, L-Theanine dan epigalokatekin galat. Ketiga zat ini saling bersinergi sehingga mampu melindungi jantung dengan membantu menurunkan tekanan darah. Tujuan penelitian ini adalah untuk melihat pengaruh pemberian teh hijau (Camellia sinensis) terhadap tekanan pada penderita hipertensi di Wilayah Kerja Puskesmas Kabupaten Aceh Selatan. Penelitian ini bersifat Quasy Experiment dengan desain pre-post kontrol grup. Sampel berjumlah 42 orang, terbagi 21 kelompok perlakuan dan 21 kelompok tanpa perlakuan. Pengambilan sampel dilakukan secara purposive sampling. Penelitian ini dilaksanakan pada bulan Februari tahun 2017. Rata-rata penurunan tekanan darah sistolik terhadap pemberian teh hijau (Camellia sinensis) pada penderita hipertensi adalah sebesar 25,33 $\mathrm{mmHg}$, sedangkan rata-rata penurunan tekanan darah diastolik terhadap pemberian teh hijau (Camellia sinensis) pada penderita hipertensi adalah sebesar 9,47 $\mathrm{mmHg}$. Ada pengaruh pemberian teh hijau (Camellia sinensis) terhadap tekanan darah pada penderita hipertensi di Wilayah Kerja Puskesmas Labuhanhaji Kabupaten Aceh Selatan $(\mathrm{p} \leq 0,05)$. Diharapkan teh hijau dapat dimanfaatkan atau digunakan oleh penderita hipertensi sebagai alternatif terapi herbal agar tekanan darah tetap normal dan stabil.
\end{abstract}

Kata Kunci :Hipertensi; Tekanan Darah; Teh Hijau (Camellia sinensis). 


\title{
INFLUENCE OF GREEN TEA (Camellia sinensis)AGAINST BLOOD PRESSURE ON HYPERTENSION PATIENTS
}

\begin{abstract}
Prevalence of hypertension in adults around the world amount $26,4 \%$ and in Indonesia is 9,5\%. In Aceh amount 30,1\% and in Aceh Selatan as much 3255 people suffered of hypertension. Green tea (Camellia sinensis) contain combination of substances that do not have in other beverages such as caffein, L-Theanine and epigalocatechin galat. These three subtances are synergized to protect the heart by helping to lower blood pressure. The purpose of this study was to see the effect of green tea (Camellia sinensis) on blood pressure in patients with hypertension. This study is quasy experiment with prepost control group design. The samples was 42 people, devided into 21 groups of treatment and 21 groups without treatment. Sampling is done by purposive sampling. This study was conducted in February of 2017. The average decrease in systolic blood pressure on green tea in patient of hypertension was $25,33 \mathrm{mmHg}$, while the average decrease in diastolic blood pressure on green tea (Camellia sinensis) in in patient of hypertension was $9,47 \mathrm{mmHg}$. There is influence of green tea (Camellia sinensis) on blood pressure in hypertension patients in work area of Puskesmas Labuhanhaji Kabupaten Aceh Selatan. It is expected that green tea (Camellia sinensis) can be used by people with hypertension as an alternative herbal therapy to keep blood pressure normal and stable.
\end{abstract}

Keywords : Blood Pressure; Green Tea (Camellia sinensis); Hypertension. 


\section{PENDAHULUAN}

Prevalensi hipertensi di NAD berdasarkan hasil pengukuran tekanan darah yaitu sebesar 30,2 \% (4). Di daerah Aceh Selatan sendiri, pada tahun 2015 terdapat penderita hipertensi sebanyak 3255 orang (Sumber : Dinas Kesehatan Kabupaten Aceh Selatan Tahun 2015). Berdasarkan data laporan rutin penyakit tidak menular di Puskesmas Labuhanhaji pada bulan Desember tahun 2016, sebanyak 68 orang dewasa menderita hipertensi (5).

Hipertensi akan menjadi masalah kesehatan yang serius apabila tidak dikendalikan. Sebab semakin lama tekanan darah pada dinding arteri dapat merusak banyak organ vital dalam tubuh manusia. Hipertensi dapat mengakibatkan komplikasi yang berbahaya dan berakibat fatal seperti stroke, penyakit jantung koroner dan gagal ginjal (16).

Salah satu upaya untuk menurunkan tekanan darah yaitu dengan pemberian teh hijau (Camellia sinensis). Beberapa studi menunjukkan bahwa teh memiliki khasiat menurunkan risiko penyakit kardiovaskular dengan menurunkan kadar kolesterol darah dan tekanan darah (17). Syah (2006) (13) mengatakan bahwa teh memiliki khasiat utama yang berasal dari polifenol yang terkandung didalamnya. Di dalam tubuh, senyawa ini membantu kinerja enzim superoxide dismutase (SOD) yang berfungsi menyingkirkan radikal bebas. Seperti yang diketahui, radikal bebas yang dihasilkan dari proses oksidasi di dalam tubuh berbahaya bagi kesehatan karena dapat menghambat aliran darah sehingga dapat menimbulkan penyakit kardiovaskular (jantung). Senyawa katekin teh hijau telah diketahui secara medis memiliki banyak manfaat seperti mampu mengurangi risiko kanker, tumor, menurunkan kolesterol darah, mencegah tekanan darah tinggi, membunuh bakteri dan jamur, membunuh virus-virus influenza dan menjaga nafas dari bau busuk (halitosisi).

\section{METODE}

Penelitian ini menggunakan desain pre dan post test kontrol grup yang bersifat Quasy Experiment. Pada desain ini terdapat kelompok perlakuan dan kelompok tanpa perlakuan. Penelitian ini bermaksud mengukur data subjek penelitian sebelum diberikan intervensi dan kemudian diukur kembali setelah diberikan intervensi. Tekanan darah kelompok perlakuan diukur saat mulai penelitian dan diukur kembali setelah 7 hari 
pemberian teh hijau (Camellia sinensis). Populasi pada penelitian ini adalah seluruh penderita hipertensi di Wilayah Kerja Puskesmas Labuhanhaji Kabupaten Aceh Selatan. Sampel dalam penelitian ini adalah penderita hipertensi di Wilayah Kerja Puskesmas Labuhanhaji Kabupaten Aceh Selatan yang diperoleh berdasarkan rumus slovin.

Pengambilan sampel dilakukan dengan cara purposive sampling berdasarkan kriteria inklusi : penderita hipertensi berusia 20-60 tahun, bersedia menjadi sampel dalam penelitian ini, tidak membedakan jenis kelamin, pasien masih dalam keadaan sadar dan bisa diajak bicara, pasien tidak sedang mengkonsumsi obat apapun, tanpa membedakan komplikasi. Penelitian ini dilaksanakan di Wilayah Kerja Puskesmas Labuhanhaji Kabupaten Aceh Selatan pada bulan Februari 2017 yang meliputi proses pengambilan data awal penelitian hingga pengurusan perijinan penelitian.

Data dianalisis dengan menggunakan uji statistik, yaitu uji "t-test dependent" pada tingkat kepercayaan 95\% $(\alpha=0,05)$ dengan memakai software SPSS seri 22 for windows. Analisis data yang dilakukan pada penelitian ini menggunakan 2 cara yaitu analisis univariat dan analisis bivariat. Analisis univariat meliputi distribusi frekuensi tekanan darah sebelum dan setelah pemberian minuman teh hijau (Camellia sinensis) terhadap tekanan darah pada penderita hipertensi di Wilayah Kerja Puskesmas Labuhanhaji Kabupaten Aceh Selatan. Tujuan analisis ini adalah untuk mengetahui apakah ada pengaruh pemberian teh hijau (Camellia sinensis) terhadap tekanan darah pada penderita hipertensi di Wilayah Kerja Puskesmas Labuhanhaji Kabupaten Aceh Selatan.

\section{HASIL PENELITIAN}

Tabel 1. Tekanan darah sistolik sebelum dan sesudah pada kelompok perlakuan dan tanpa perlakuan di Wilayah Kerja Puskesmas Labuhanhaji Kabupaten Aceh Selatan Tahun 2017

\begin{tabular}{lcccccc}
\hline \multirow{2}{*}{ Tekanan Darah } & \multicolumn{3}{c}{ Kelompok Perlakuan } & \multicolumn{3}{c}{ Kelompok Tanpa Perlakuan } \\
\cline { 2 - 7 } & Mean & Min & Max & Mean & Min & Max \\
\hline Sistolik sebelum & 163,62 & 142 & 200 & 157,00 & 141 & 205 \\
Sistolik sesudah & 138,29 & 120 & 178 & 154,62 & 130 & 181 \\
\hline
\end{tabular}


Kelompok perlakuan didapatkan bahwa rata-rata tekanan darah sistolik sebelum pemberian teh hijau (Camellia sinensis) pada penderita hipertensi adalah 163,62 $\mathrm{mmHg}$, sedangkan rata-rata tekanan darah sistolik sesudah pemberian teh hijau (Camellia sinensis) pada penderita hipertensi adalah 138,29 mmHg. Pada kelompok tanpa perlakuan dapat dilihat bahwa rata- rata tekanan darah sistolik penderita hipertensi sebelum adalah 157,00 $\mathrm{mmHg}$, sedangkan tekanan darah sistolik sesudah adalah 154,62 $\mathrm{mmHg}$.

Tabel 2. Tekanan darah diastolik sebelum dan sesudah pada kelompok perlakuan dan tanpa perlakuan di Wilayah Kerja Puskesmas Labuhanhaji Kabupaten Aceh Selatan Tahun 2017

\begin{tabular}{lccccccc}
\hline \multirow{2}{*}{ Tekanan Darah } & \multicolumn{2}{c}{ Kelompok Perlakuan } & \multicolumn{2}{c}{ Kelompok Tanpa Perlakuan } \\
\cline { 2 - 6 } \cline { 5 - 8 } & Mean & & Min & Max & Mean & Min & Max \\
\hline Diastolik sebelum & 95,57 & 80 & 115 & 90,76 & 70 & 105 \\
Diastolik sesudah & 86,10 & 79 & 98 & 88,95 & 69 & 105 \\
\hline
\end{tabular}

Analisis data pada kelompok perlakuan didapatkan bahwa pada kelompok perlakuan rata-rata tekanan darah diastolik sebelum pemberian teh hijau (Camellia sinensis) pada penderita hipertensi adalah $95,57 \mathrm{mmHg}$, sedangkan rata-rata tekanan darah diastolik sesudah pemberian the hijau (Camellia sinensis) pada penderita hipertensi adalah 86,10 mmHg. Pada kelompok tanpa perlakuan dapat dilihat bahwa rata-rata tekanan darah diastolik penderita hipertensi sebelum adalah 90,76 $\mathrm{mmHg}$, sedangkan tekanan darah diastolik penderita hipertensi sesudah adalah $88,95 \mathrm{mmHg}$.

Tabel 3. Pengaruh pemberian Teh Hijau (Camellia sinensis) terhadap tekanan darah pada penderita hipertensi di Wilayah Kerja Puskesmas Labuhanhaji Kabupaten Aceh Selatan Tahun 2017

\begin{tabular}{lllllllllll}
\hline \multirow{2}{*}{$\begin{array}{l}\text { Tekanan } \\
\text { Darah }\end{array}$} & \multicolumn{4}{c}{ Kelompok Perlakuan } & \multicolumn{4}{c}{ Kelompok Tanpa Perlakuan } \\
\cline { 2 - 10 } & n & Mean & SD & t & p & n & Mean & SD & t & p \\
\hline Sistolik & 21 & 25,33 & 8,375 & 13,862 & 0,000 & 21 & 2,38 & 7,684 & 1,420 & 0,171 \\
Diastolik & 9,47 & 5,474 & 7,933 & 0,000 & 1,81 & 5,930 & 1,398 & 0,177 \\
\hline
\end{tabular}


Pada kelompok perlakuan, rata-rata penurunan tekanan darah sistolik karena pemberian teh hijau (Camellia sinensis) pada penderita hipertensi adalah sebesar 25,33 $\mathrm{mmHg}$, sedangkan rata-rata penurunan tekanan darah diastolik adalah sebesar 1,81 mmHg. Hasil uji statistik dengan menggunakan uji T-Test Dependent pada kelompok perlakuan tekanan darah sistolik didapatkan adalah sebesar 9,47 mmHg. Adapun pada kelompok tanpa perlakuan, rata-rata penurunan tekanan darah sistolik pada penderita hipertensi adalah sebesar 2,38 $\mathrm{mmHg}$, sedangkan rata-rata penurunan tekanan darah diastolik terhadap kepercayaan 95\%, sedangkan uji statistik terhadap tekanan darah diastolik pada kelompok perlakuan didapatkan nilai $\mathrm{p} \leq(0,05)$ pada tingkat kepercayaan 95\% sehingga dapat disimpulkan bahwa pada kelompok perlakuan ada pengaruh pemberian teh hijau (Camellia sinensis) terhadap tekanan darah pada penderita hipertensi di Wilayah Kerja Puskesmas Labuhanhaji Kabupaten Aceh Selatan.

\section{PEMBAHASAN}

Penelitian ini menyatakan bahwa teh hijau (Camellia sinensis) sangat baik untuk diberikan kepada penderita hipertensi, karena teh hijau (Camellia sinensis) terbukti mampu menurunkan tekanan darah penderita hipertensi, baik tekanan darah sistolik maupun diastolik. Penurunan tekanan darah pada kelompok perlakuan sendiri terjadi karena pasien hipertensi mau meminum seduhan teh hijau secara teratur selama 7 hari sesuai dengan cara dan jumlah takaran yang telah direkomendasikan.

Penelitian ini sejalan dengan penelitian yang dilakukan oleh Sriyono dan Proboningsih, J. (2012) (11) dengan judul "Pengaruh Pemberian Teh Hijau Terhadap Tekanan Darah dan Kadar Kolesterol (LDL) pada Lansia dengan Hipertensi” yang menyatakan bahwa terdapat perbedaan tekanan sistolik dan diastolik sebelum dan sesudah diberi teh hijau. Sedangkan kadar kolesterol sebelum dan sesudah diberi teh hijau tidak terdapat perbedaan secara bermakna.

Antioksidan berperan penting dalam menangkis dan menghambat pembentukan lapisan lemak pada dinding pembuluh darah (arteri) yang disebut atherogenesis. Dengan begitu, seluruh arteri terutama pembuluh darah koroner akan terbebas dari penebalan dinding akibat tempelan/plak lemak atau kolesterol. Inilah pentingnya asupan zat-zat antioksidan untuk mencegah stres oksidasi dan atherogenesis. Bahan aktif yang terdapat 
pada minuman teh adalah polifenol yang bersifat antioksidan, yaitu melawan radikal bebas yang terbentuk dalam proses metabolisme di tubuh kita. Radikal bebas akan memicu terjadinya stres oksidasi yang sangat merugikan tubuh, sehingga konsumsi polifenol sangat dibutuhkan oleh tubuh.

Teh hijau mengandung flavonoid yang memiliki kemampuan dalam menghambat pembentukan kerja enzim angiotensin transferase. Seperti kita ketahui ACE tersebut berperan sebagai pembentukan angiotensin II yang akan mempengaruhi pembuluh darah yaitu dengan vasokontriksi dan menaikan ekskresi garam dan air di ginjal sehingga mengakibatkan tekanan darah naik. Dengan dihambatnya ACE oleh flavonoid dalam teh hijau maka proses tersebut akan terhambat sehingga pembuluh darah dapat bervasodilatasi mengakibatkan Total Perypheal Resistensi (TPR) akan menurun selain itu ekskresi air dan garam di ginjal juga akan menurun sehingga cardiak output menurun dan tekanan darah turun (Syah, 2006) (13).

\section{Kesimpulan dan Saran}

Rata-rata tekanan darah sistolik pada kelompok kasus sebelum mengkonsumsi teh hijau (Camellia sinensis) adalah 163,62 mmHg. Sedangkan rata-rata tekanan darah diastolik pada kelompok kasus sebelum mengkonsumsi teh hijau (Camellia sinensis) adalah 95,57 mmHg. Rata- rata tekanan darah sistolik pada kelompok kasus sesudah mengkonsumsi teh hijau (Camellia sinensis) adalah 138,29 mmHg. Sedangkan rata-rata tekanan darah diastolik pada kelompok kasus sesudah mengkonsumsi teh hijau (Camellia sinensis) adalah 86,10 mmHg. Ada pengaruh pemberian teh hijau (Camellia sinensis) terhadap tekanan darah pada penderita hipertensi di Wilayah Kerja Puskesmas Labuhanhaji Kabupaten Aceh Selatan $(\mathrm{p} \leq 0,05)$. Diharapkan melalui peran ahli gizi di Puskesmas agar dapat memberikan penyuluhan/konsultasi pada penderita hipertensi sehingga dapat menjadikan teh hijau sebagai alternatif terapi herbal agar tekanan darah tetap normal dan stabil.

\section{REFERENSI}

1. Anantaboga, J. (2012) Tangkal Seabrek Penyakit dengan Teh Hijau, DIVA Press, Jogjakarta.

2. Adriani, F. (2010). Pemberian Ekstrak The Hijau Menurunkan Berat Badan, Lingkar Perut, dan Persentase Lemak Tubuh pada Wanita Kelebihan Berat Badan yang melakukan Latihan Fisik dengan Pola Makan Biasa. Program Magister, Program Studi Ilmu Biomedik, Program Pasca Sarjana, Universitas Udayana, Denpasar. 
3. Dewi, K. (2008). Pengaruh Ekstrak Teh Hijau (Camellia Sinensis var. Assamica) Terhadap Penurunan Berat Badan, Kadar Trigliserida dan Kolesterol Total pada Tikus Jantan Galur Wistar. Fakultas Kedokteran, Universitas Kristen Maranatha.

4. Departemen Kesehatan RI. (2007) Riset Kesehatan Dasar Provinsi Nanggroe Aceh Darussalam. Badan Penelitian dan Pengembangan Kesehatan Departemen Kesehatan RI, Jakarta.

5. Kementerian Kesehatan RI. (2013) Riset Kesehatan Dasar. Badan Penelitian dan Pengembangan Kesehatan Kesehatan RI, Jakarta.

6. Melati, HP. (2009) The Magic of Tea, Hikmah, Jakarta Selatan.

7. Saraswati, A. (2015) Efektivitas Ekstrak Daun Teh Hijau (Camellia sinensis) dengan NaOCI 2,5\% terhadap Bakteri Enterecoccus faecalis sebagai Alternatif Larutan Irigasi Saluran Akar. Bagian Ilmu Konservasi Gigi, Fakultas Kedokteran Gigi, Universitas Hasanuddin, Makasar.

8. Saraswati, S. (2009) Diet Sehat Untuk Penyakit Asam Urat, Diabetes, Hipertensi, dan Stroke, Aplus Books, Jogjakarta.

9. Soraya, N. (2007) Sehat dan Cantik Berkat Teh Hijau, Penebar Swadaya, Jakarta.

10. Sriwahyuni, E., Puspita, T.,\& Putranti, H. A. P. (2007) "Pengaruh Pemberian Teh Hijau Terhadap Kadar Kolesterol LDL dan HDL pada Tikus Putih (Rattus norvegicus strain wistar). Majalah Kesehatan FKUB Vol 3 No. 1, halaman 1-10.

11. Sriyono \& Proboningsih, J. (2012) Pengaruh Pemberian Teh Hijau Terhadap Tekanan Darah dan Kadar Kolesterol (LDL) pada Lansia dengan Hipertensi. Jurnal Keperawatan Soedirman (The Soedirman Journal of Nursing) Vol. 7 No. 1, halaman 36-43.

12. Suiraoka, IP.(2012)Penyakit Degeneratif, Mengenal, Mencegah dan Mengurangi Faktor Risiko 9 Penyakit Degeneratif, Nuha Medika, Yogyakarta.

13. Syah, A.N (2006) Taklukkan Penyakit Dengan Teh Hijau, PT. Agromedia. Pustaka, Jakarta.

14. Syaifuddin, M., Sudaryanto, A., \& Maliya, A. (2013) Penggunaan Tanaman Herbal pada Lansia Penderita Hipertensi di Kec. Gatak Kab. Sukoharjo. Fakultas Ilmu Kesehatan, Universitas Muhammadiyah Surakarta. http://www.eprints.ums.ac.id/ 27208/25/NASKAH PUBLIK ASI.pdf

15. Ukra, M. (2008) The Miracle of Tea, terjemahan oleh Arfan Achyar, 2011. Mizan Publika Publishing House, Jakarta Selatan.

16. Widyanto, FC. \& Triwibowo C. 2013) Trend Disease "Tren Penyakit Saat Ini”, Trans Info Media, Jakarta.

17. Winarti, S. (2010) Makanan Fungsional, Graha Ilmu, Yogyakarta. 